\title{
ARTICOLE
}

\section{THE NEW CIVIL PROCEDURE CODE IN HUNGARY}

\author{
DOI:10.24193/SUBBiur.62(2017).1.4 \\ Published Online: 2017-03-15 \\ Published Print: 2017-03-30
}

\section{László PRIBULA*}

\begin{abstract}
The new Hungarian Civil Procedure Code comes into effect on 1 January, 2018. The new code aimed to create a regulation which is based on the responsible litigation of the parties and the active procedure litigation of the judiciary to ensure the presumptions of a concentrated process. During the forming of the code, the legislator made use of the experiences of the right judicial practice, and also took into account the decade-long researches of legal literature, and was eager to learn from foreign examples. It introduced several new legal institutions such as the divided process structure, process caesura, substantive litigation, collective assertion of claims. The appropriate application of these lies in the judicial practice. It is up to the future to decide whether the new code is able to establish an efficient and successful process order which meets the requirements of the modern age.
\end{abstract}

Keywords: Hungarian New Code of Civil Procedure, principles of civil procedure, divided structure of civil procedure, professional litigation, substantive litigation

\section{The necessity of the new civil procedure code}

Creating a new code of civil procedure plays a crucial part in a certain state's history of law. No matter how elaborate and detailed rules of material law exist, civilians who are searching for their rights would not be able to vindicate their rights effectively and successfully without an up-to date system of rules that is wrought to answer the needs for the claims, follows traditions and meets the requirements of the age. In the past few years Hungarian legislators wished to realise the three great procedure laws at the same time, namely to carry through the laws about penal procedure, administrative procedure and civil procedure. Among these to top the list, Hungarian Parliament passed Act CXXX of 2016 on the Code of Civil Procedure on 22 November 2016. 
One of the most important acts in Hungarian history of law was Act I of 1911, the first Hungarian Code of Civil Procedure, the result of the decade-long arranging work of Sándor Plósz, the excellent professor of law and practicing expert. This law, including the promotion of the parties' right of action, the principle of public hearing, the priority of orality, and the ensuring of instruments to make the trial effective, has already contained features, which may also be expected from an up-to-date present-day civil procedure code. Legal literature unanimously thinks that the regulations of the 1911 code were clear-cut, logical, and they were adjusted to real practical problems. The Soviet-type regime, however, abrogated this code, just like the traditional court system, and introduced the second Hungarian Code of Civil Procedure of Act III of 1952 instead, which was in effect for more than fifty years.

During the past decades, especially after the change of political regime, the second Civil Procedure Code underwent significant changes resulting in a decreased role of trial courts and an increased role of legal institutions that accelerate the legal process. The demand still showed up both in practice and in jurisprudence for the creation of a new civil procedure code based on a fundamentally different concept. First, as a result of a decade-long preparation, the legislator effectuated a new civil substantive law: Act $V$ of 2013 on the Civil Code, which came into force on 15 March, 2014. The approach of the Civil Code determined the concept of the implementation of the recognised substantive laws, as it put forward the ideal of the independent, autonomous, responsible entity, promoting conscious, responsible, well-prepared, and professional assertion.

It was debated whether it is enough to amend the effective Civil Procedure Code, or is it necessary to create a fundamentally new code. The majority of jurists, lawyers and legislators agree that even though the jurisdictional practice has successfully accommodated to the challenges following the change of political regime, the radically changed social and economic conditions require a more modern regulation which helps to arrange the complex legal disputes efficiently, and which integrates the well-functioning procedure regulations of other countries. The main reason behind this was that, even though the previous code which was effectuated more than sixty years ago does not consist of the socialist procedure law any more, still the ideological starting point has been passed as a basis for possible amendments. After the change of regime, the code has been amended for more than a hundred times, thus breaking the unity of regulation and forming inconsequence in the text. Moreover, one of the main expectations, process efficiency was to be reached mainly by the continuous aggravation of deadlines, but process structure remained intact. All these facts made the comprehensive renewal of civil procedure necessary.

It was obvious during codification that - leaving the discussions on founding administrative courts intact, which topic is to be detailed later - it is not necessary to alter the historically-based four-level court system, and to change the court model which divided technical and administrative control, and which was introduced in 2011.

When the legislator decided on making the new code, it had to declare which European country's civil procedure code it would use as a model. For historical reasons it was German and Austrian law that had the greatest effect on the development of Hungarian law history. At the same time, the consequences of the historical events and the geographical position 
created the same problems in Central European Countries. The new Hungarian Civil Procedure Code looked on the 1877 German procedure code (Zivilprozessordnung - ZPO), the 1895 Austrian civil procedure code (öZPO), and the 2008 Swiss federal civil procedure code (schZPO), but it also wished to examine the lessons of the Central European (Slovenian, Lithuanian, Croatian, and Romanian) civil procedure codes of the past few years.

There seem to be a consensus in Hungarian legal literature concerning the dual function of civil procedure law. It can only be effective in the individual and abstract defence of rights if it is built on five pillars: 1.) it acknowledges the parties' right of action, namely that it is the right of the parties to initiate action and assert the rights involved; 2 .) it is an inquisitorial system, which entrusts the parties and not the court to supply the material for the trial; 3 .) it is based on the independent use and consideration of evidence; 4.) it restricts and sanctions the misuse of procedural rights, or chicanery; 5 .) it offers help for the indigent - either as a result of their level of income, property status, or their inaptness in law - to assert their rights in front of a court. When the arrangements of the new civil procedure code began, it was beyond dispute that the new code will rest on these requirements.

The formation of the new civil procedure code cannot be autotelic: the necessity of the codification can only be justified if it is able to create institutions and guaranties by which it can promote the development of an effective application of laws. In order to facilitate this endeavour, during the elaboration of the provisions of the law, the legislator hugely had to rely on the experience of the different branches of lawyers, the achievements of jurisdiction, and the law-developing interpretation of judicial practice. The legislator recognised the legitimacy of this need, and aimed to involve as many theoretical and practical experts as possible during the codification process.

The Hungarian Government decided on the codification of the procedural law with Government Decision No. 1267/2013 (V. 17.) It aimed to create an up-to-date civil procedure code which relies on the achievements of jurisdiction and court practice, and meets the expectation and practice of international practices, and which efficiently ensures the assertion of substantive laws. It decided on establishing of a Civil Procedural Law Codification Chief Committee, the members of which are renowned legal experts and practicing professionals.

It requested the Minister of Law to develop the concept of the new civil procedure code, to initiate a professional and social discussion, and, finally, to formulate the new code. The committees responsible for the certain topics laboured the concept of the law, which served as the base for the new civil procedure code developed by the Ministry of Law, which was passed by the Government on 14 January, 2015. Then the Minister of Law called for working committees to develop the standard text, which was the preparation for a comprehensive experts' proposal. ${ }^{1}$ Utilising the experts' proposal, even though based on a partially different concept, the Ministry of Law - under the lead of a specially commissioned ministerial commissioner - finalised the standard text, and the Ministry of Law submitted the proposal to the Parliament in September, 2016. After the debate of the proposal, the Parliament passed the law with minor amendments. 
Based on an intensive professional and social debate, we can conclude that, even though there were different points of views, the passed law did not receive strong philippic criticism, neither from the public opinion, nor from the legal professions. Unlike the administrative procedure code, the civil procedure code did not receive political significance, and the media presented it from professional aspects.

\section{Conceptual Changes in the New Code of Civil Procedure}

The significant conceptual changes in the new code are the followings:

1. One of the greatest strategic changes is that, in the future, the rules of administrative proceedings are not included in the civil procedure code any more, but the new, independent administrative procedure code, which will refer to the previous code only as a background law. According to the previous solution, administrative actions, as special civil actions were included among the special provisions of the civil procedure code. It was the case even though administrative actions showed substantial differences to civil actions concerning the purposes, the tools of legal defence, and the typical processions. Judicial control over administration includes the assertion of the material rights beyond the subjective legal defence of the parties, thus, as a result, the right of action is limitedly asserted, authority's evidence has a greater role, and the action position of the parties has to be assessed differently since they are in a subordinate/superordinate relationship determined by common law. These aspects justify the clear-cut division of administrative and civil actions. The new regulatory system, however, does not only result in that regulations concerning administrative actions are omitted from the civil procedure code, but the development of administrative jurisdiction also affects the competence of civil jurisdiction. While previously the legislator classified only the judicial review of administrative decisions among the administrative proceedings, the new administrative procedure code aimed to ensure the complete and effective legal defence against administrative authorities ${ }^{2}$, satisfying a criterion long expressed in legal literature. As a result, not only the judicial control of the administrative authority's individual decisions are referred to the judicial channel, but also those decisions of the administrative authority which target or result in a change in the entity's legal position, in case the decision is regulated by administrative law. Another consequence of the development of the judicial channel is that individual disputes which earlier fell under the civil procedure, will fall under the concept of administrative action in the future. Thus, first and foremost, the legislator expands the concept of administrative dispute also to administrative contracts which were earlier proceeded according to the general rules of civil substantive law, arguing that contracts concluded by administrative authorities when exercising public power cannot be characterised by the features of the legal relationship of private law, but rather the asserting of public interest, and the resulting limited right of action. However, the civil procedure code does not generally define the concept of administrative contracts, but entrusts it on individual laws or government decisions in order to classify them as administrative. Similarly, it enlists among administrative proceedings the classification of civil service disputes which previously belonged to private labour law disputes, as these originate in the legal relationship of persons who are 
employed by the state for the common good. After lengthy debates compensation proceedings for damages caused in administrative legal power were not included among administrative but civil disputes, similarly to the German solution. The new regulation, however, binds the hands of civil courts in terms of procedure law, since the condition of being able to assert a claim for a damage caused in administrative legal power is that the proceeding court has to establish the violation of right in a final judgement. ${ }^{3}$

The final decision of the court concerning an administrative proceeding binds the hands of the civil court. ${ }^{4}$ No decision has yet been made about whether the independent administrative procedure law is bringing forth an independent administrative judicial system of organisation in the future. Beyond the professional debates social, public, and political differences has emerged.

The legislator decided to renew administrative jurisdiction completely, which is planned based on three superimposed alterations: one is the creation of detached procedure regulations for administrative lawsuits, the other is a partial change in the structural framework of administrative jurisdiction, while the third is the modification of the selective conditions of administrative judges. In August 2016 the practicing lawyers could learn about the legislator's ideas which concern the amendments of administrative jurisdiction, its legal status and the structural laws.

Before 2013, there were no administrative courts in Hungary, not even partially functioning Administrative and labour courts were founded on 1 January, 2013 in every county, as the successors of labour courts acting since 1972 as specialised first-instance courts, which, however, were differentiated from the normal court structure only at first instance. According to the legislator's plans about the differentiated administrative jurisdictional structure, regional administrative courts would act at first instance in several counties, the sole administrative appeal court would act at second instance and at first instance in cases of high priority, while technical control of administrative courts would be the duty of the Curia, the uppermost-level court of the normal Hungarian jurisdictional structure. The necessity of restructuring was justified by the opportunity to specialise, because the smaller number of cases as compared to civil lawsuits requires lower-level regional administrative courts of greater regional competence on the one hand, and on the other hand, specialised upper-level courts with competence over the whole country. According to the plan to alter the personal conditions, the special appointment of administrative judges would be determined as compared with the appointment of judges, namely that a person can be appointed to administrative judge who, after fulfilling the conditions to become a judge and passing the bar exam, had specialised in administrative law for at least five years, while to half of the administrative judicial positions a person can be appointed, who, after passing the bar exam, has specialised in administrative law for at least ten years, but not as an administrative judge.

According to the justification of the alteration, besides knowledge of administrative law and of administration, professional experience of administrative law is significantly important, as verified by international examples. For example in Poland and Portugal, a 
long-term experience is expected, while in Austria and Bavaria, the regulation significantly promotes rotation.

The draft generated huge debates, it was also criticised by the National Judicial Office, especially for the unsolved conditions of labour jurisdiction, the difficulties in personal conditions originating in the regional competence instead of county competence, such as the employees moving into another town, or the complicated case maintenance when a place of jurisdiction materialised, or as a result of losing the advantages of a unified judicial organisation. Finally the debate arrived to a political space, and since the parties of the opposition did not support it, the legislator did not even attempt to amend the law on the legal status of judges and the judicial structure, which draft would have required a two-third majority. On 6 December, 2016, with simple majority the Parliament passed the law on administrative procedure separated from civil procedure, which, however, did not change the judiciary structure, but the majority of administrative lawsuits were referred to eight regional administrative and labour courts, while the courts in the capital were renamed "courts acting as administrative appeal court", and assured for them a first-instance competence in cases of priority, and a national second-instance competence. The president of state, however, alluding to constitutional nullity, referred the law to the Constitutional Court, which annulated the regulation of administrative procedure code which related to "court acting as administrative appeal court", justifying by that the legislator would actually create a new court, which would have required a two-third majority amendment of the judiciary structure law. At the same time the Constitutional Court annulled the regulations of elections and media authorities, both requiring two-third majority. ${ }^{5}$

2. The structure of the civil procedure law adjusts traditional solutions. The foundations are followed by the establishment of the static rules of the civil procedure concerning the courts, the parties, the costs of proceeding -, then by the dynamic rules of legal acts ranging from the statement of claim to the final decision. The regulations of the proceeding at first instance, the appeal proceeding, and the extraordinary remedy are discussed separately. Finally the code arranges the special proceedings which require special instruments because of their subject or the personality of the parties. The question emerged that the procedure code could have included the basic regulations of non-contentious proceedings which can be found in several other laws, especially because of their relationship to the legal proceedings, but this proposal was rejected by the legislator.

It is, however, worthwhile to pay attention to the technical comment that the often conceptually significant changes will affect a great number of non-contentious proceedings, as these regulations are often applied in the background of such proceedings. ${ }^{6}$

3. The law includes the special principles of the civil proceedings only in the most necessary measure. It treated the solutions of the Swiss civil procedure code in effect from 2011 as an example, which included only a short conceptual section enlisting the most important directions. It is careful not to burden the procedure law with general principles of 
human rights, constitution, or the operation of justice which are norms of civil procedures. It defines only the principles which allocate the technicalities of civil procedures in short, abstract formulas. Above the traditional principle of disposition, which includes bringing court action at request, the fact that the court is bound to the submitted request and to the legal statement, and free disposition with the rights involved in the action, the new principle is the principle of procedure concentration, which expresses the efficient defence of rights. According to the latter principle - with regard to the 2006 propositions of CEPEJ (European Commission for the Efficiency of Justice) which prioritised the efficiency of lawsuits -, both the judicatory and the parties have to endeavour to present all the facts and evidences necessary for the decision in time in order to make the dispute ready to be judged in one hearing. It does not mean implicitly that the case must be judged in one hearing, but the legislator considers it important to express a message which urges all the participants to litigate and finish the proceedings as quickly as possible. ${ }^{7}$ Procedure concentration results in the parties' obligation to support the proceeding on the one hand, as the parties are obliged to promote the concentrated litigation and finishing, ${ }^{8}$ and, on the other hand, the ministering activity of the judicature, as the judicature assists the parties to fulfil their procedural obligations utilising the ways and instruments defined in the law to vindicate procedure concentration. ${ }^{9}$

Accentuating the concern in the concentrated litigation and finishing of the proceeding alone may remain a mere wish if the legislator does not introduce institutions which are able to promote the real predomination of the principle. Of these the legal appearance of the institution of substantive litigation generated the greatest technical debate and interest. ${ }^{10}$ As opposed to the Soviet-type procedure code, the role of the judiciary is not paternalistic, resulting from the principles of disposition and of public hearing, so it cannot take over the obligation to present material for the proceeding, neither can it make up for the lack of the parties' legal knowledge. The judiciary cannot be responsible for providing information about the substantive laws, neither for undertaking ex officio probation in the sphere of the parties' interest if it is not offered. However, the judiciary cannot be completely passive. It cannot restrict itself merely to determining the procedural acts and to maintaining the order and merit of the proceeding. In order to finish a civil proceeding quickly, efficiently, and successfully, it is essential to neglect the unnecessary propositions for evidence and to litigate a concentrated probation. For this aim one needs to presume a fully comprehensive presentation of statement of claim based on relevant facts, in accordance with the rights involved in the action, and an also comprehensively reacting counter-statement, in addition the exact definition of the facts to be evidenced and the burden of proof within the framework of the statement and the counter-statement. Inconsistent statements eventuate a lengthy continuance of procedure. The requirement concerning the judiciary to promote adequately detailed and consequent declarations from the parties' in order to exactly define the dispute does not interfere with the interpretation of the role of the judiciary. The necessary instruments such as questioning, calling for declaration, informing about the framework of the dispute, must be provided for the judiciary. The legislator realised this when 
they defined the substantive requirements of litigation for the judiciary within the limits of the parties' requests and statements. The new institution, nevertheless, will probably not cause practical problems, since substantive litigation of procedure has implicitly existed, the right judicial practice has been applying it correctly. Substantive litigation can ensure procedure concentration without the injury of the parties' procedural rights only if the requisition of legal literature is asserted, namely that the parties' can only receive support from the judiciary for their needs during the procedure. ${ }^{11}$

4. Another essential change in the new civil procedure code is the introduction of divided structure of procedure, which are has been applied by the paradigmatic German and Swiss civil procedure codes, and which has been effectuated by certain Central European countries such as Slovenia, Croatia or the Czech Republic. The previously effective procedure code did not divide the first instance civil proceedings into legally ascertained sections, but treated them as one unit. This arrangement implied the risk that in a relatively late section of the first instance the parties' could alter their statements, presentations, or claims in such a measure that made all the previously performed actions unnecessary, giving way to the prolonging of the procedure. The new code wishes to interfere by arranging a sequence in which the parties' have to give statement first, then secondly produce evidence for their statement but they cannot alter their statement depending on the outcome of the evidence. That is why the first instance procedure resolves into two sections, divided by a judiciary decision. The first section is called the procedure entry section. The aim of the procedure entry section is to define the framework of the dispute, in this section the claimant has to present the statements of facts, of allegement, and of claim, while the respondent has to present an exhaustive response for the claim as well. In this section the parties' have to submit evidence according to their statements, and there is opportunity to perform several legal acts only in this section, such as intervening on either party's side, alteration of the parties' person. The judiciary closes the procedure setup section with an unappeasable court decision called procedure caesura, and then in the second, substantive dispute section the substantive evidencing acts take place. It is not impossible that an unpredictable circumstance which is beyond the parties' responsibility justifies the redefinition of the framework of the dispute, based on which even after the finished entry section, the statement or the counterstatement can be altered, new evidence claims can be proposed, and in this exceptional situation the entry can be amended as explicitly permitted by the judiciary, according to strict procedure regulations. From the introduction of the divided procedure structure the legislator expects that "it encourages the parties to a more intensive preparation, and enables a more concentrated, tighter procedure."12 The presumption for it is that the reopening of the procedure entry section is possible only in extremely exceptional cases.

5. The new civil procedure code wishes to enforce the requirement of professional litigation. According to the previous arrangement legal representation was required only exceptionally, in certain implicitly important cases, and for parties turning to appeal courts. 
Instead, the new law models the procedure to compulsory legal representation. The Hungarian judicial structure system - apart from the administrative and labour courts which are independent only at the first instance level - is a traditionally four-level system: district courts ("járásbíróság"), which have only first instance competence, are at the basic level, on the next level there are the regional courts ("törvényszék") acting partly on first, partly on second instance level, at the next level there are the regional courts of appeal ("itélótábla"), which act only on second instance, and at the highest level there is the Curia ("Kúria"), which is responsible for the unity of law application, and it proceeds in cases of review against final judgements only on the grounds of infringement. A dual entrance level adapts to the four-level court system. Everyday cases requiring simple decisions start at the district courts, while more complicated cases which demand special knowledge, start at the regional courts. As opposed to the earlier model, however, the legislator assigns regional courts as general first instance courts, and only exceptionally defines the competence of the district courts, not making actual changes in the proportion of the distribution of cases. Basically the reason for it is that regional courts own juridical personality, the judicial college which is responsible for the professional co-operation of the judges is organised there, moreover, it is also supported by the previously discussed endeavour to model the procedures on a professional processing. During court procedures, legal representation is obligatory for all parties, without legal representation their statements are treated as invalid. The official necessity for an advocate is not formal, there are strict requirements. The code particularly defines both the assumptions of the claimant's statement of claim and the respondent's counter-statement, and deficient statements have no ground for substantive dispute, as no supplication is possible for a deficiency, according to the directions of the law. From these regulations the legislator assumes expects a strengthened professional responsibility of legal representation and, indirectly, an increase in efficiency. In certain cases, however, such as matrimonial, paternity and genealogical processes or processes for smaller assets, where legal representation cannot be required, the legislator wishes to promote efficiency by supplying forms to fill in and a wider opportunity of call for deficiency supplementation.

6. The legislator wants to adjust the rules of evidence to the substantial characteristics of the civil process. Improper judicial practice pragmatically enforced the regulation that the party (claimant) who wants to assert a claim has to allege the facts, and also bears the burden of proof. The extreme expectation of the claimant's and the respondent's burden of proof did not take into account the previous acts of the parties. The case may emerge when the reason for the claiming party's inability to state the claim or to supply evidence is exactly the nonsupporting attitude of the other side. So the new civil procedure law introduced the concepts of emergency of statement and emergency of evidence by which it aims to dissolve the wrong pragmatic interpretation. Even though, as a general rule, the party still needs to state facts which party wants to assert a claim, but if the party renders it probable that only the other side possesses the necessary information needed to allege facts, and the party has already done everything to get the information, but still has not been able to get it due to the attitude of the other side, then the party is in an emergency of statement, which is the base for the judge to accept the statement as real. ${ }^{13}$ If it is the other side who exclusively possesses the necessary 
information for evidence, the other side can be expected to prove the unreality of the statements, or if the other side defeated the success of proof, then the party is in an emergency of evidence, providing base for the judiciary to accept the evidence as real. ${ }^{14}$

7. While neither the legislator nor those who apply the law question that based on the principle of hearing it is the duty of the parties to supply the material for the process, and any kind of evidence can be used in the dispute which is necessary to state the case, this principle was not applied consequently in the expert evidence. The previous practice excluded the facts presented by the expert (private expert) from the circle of evidence if the expert was commissioned by the party, and treated them as the party's private presentation. However, in the case when the expert evidence takes place exclusively at the judiciary' assignment, answering only the questions of the judiciary, the parties' responsible litigation may be effaced. This approach is rooted in the view shared by a majority that the expert is the judge's colleague, or helper, as a study put it, a "scientist judge." ${ }^{15}$ In contrast with this practice, the expert is of among the evidence tools, and the independent evidence system is consequent if it does not neglect the conclusions of the expert opinion. That is why the law defines the application of a private expert commissioned by the party with guaranties of the appropriate process regulations as primary, with the reservations that the forensic expert must possess the adequate qualification, skill, and entitlement, and the expert must give comprehensive responses to the questions and reflections of not only the commissioning party, but also the other side. The opposition of the evidencing party also has the right to commission a private expert, in this case the occurring discrepancies must be solved. Applying an expert based on the judiciary's commission can take place only secondarily, if there is no private expert involved, or if the presented expert opinion is ambiguous, and also in this case the parties have to ask questions to the expert.

Even though the previous law did not acknowledge the private expert's opinion and the one's commissioned by the judiciary as equal, in practice it did not hold back the parties from enclosing their private experts' opinions without limit and control, which practice resulted in uncertainty. From the new model of evidence the legislator expects the acceleration of the processes.

8. According to the legislator's intention, the parties' right to action will prevail more emphatically in the second instance procedures. Appeal courts were criticised for countermanding first instance decisions more often than it was justified, and for directing the first instance courts to rehear the cases and to carry out new decisions, even if it was not the expressed intention of either party. The civil procedure code which is still in effect facilitates countermanding depending on the court's deliberation in cases when the essential regulations of the first instance process are violated, independently from the parties' reference to violation. The substantial rule of the new civil procedure code is that the second instance court can practice the power of revision within the limits of the parties' claims. Apart from exceptional, extremely serious violations of procedure rules, which result in obligatory countermanding (contribution of a dismembered judge, non regulated forming of the judicial committee) the second instance court cannot take into account the violation of procedure 
rules that is not referred to in the appeal. ${ }^{16}$ Moreover, the conditions of the considerable countermanding became stricter. For this, it is not sufficient alone that the first instance court violated essential rules which the parties' pronouncedly pled, and it affected the substantial decision of the case, but also that remedy is not at all feasible or only irrationally feasible (in a very long period). ${ }^{17}$ Restriction or exceptionalisation of countermanding serves both the interest of civilians asserting their rights and of legal practice, the legislator strongly wished to promote this aim.

9. The introduction of procedures of collective assertion of claims, a previously unknown institution, is an important change in Hungarian legal system. In several cases, especially because of the retentivity of the disproportionately high legal costs compared to the value of the claims, the individual cannot initiate an action against en-masse, frequent violations, while the consequences of the wrong behaviour can be repelled or compensated only in co-operation. According to one of the renowned experts on the topic, the establishing of new procedure mechanisms is enhanced by the fact that such co-operations increase the equality of power, thus they can help rebalance the disparities of resources and power imbalances. ${ }^{18}$ The legislator introduced two new special types of processes: processes of public interest and joint processes. The essence of the former ${ }^{19}$ is that explicitly authorised individuals and organisations are permitted to bring a suit to protect public interest, and the substantive power of the decision extends to those entitled but not involved in the suit, in case the respondent informed them about the judgement-at-law, and they did not declared that they reserve their right of action. The essence of the latter ${ }^{20}$ is that in proceedings originating in customer contracts, and in actions for damages concerning labour law or caused by environment pollution, at least ten claimants can assert their substantially similar rights in co-operation, and only one "representative" claimant has to act practically, while the substantive power of the judgement-in-law extends to all of them.

10. During the process of codification there were debates about the proposition that the civil process of the $21^{\text {st }}$ century should omit the written record, and instead requires the continuous voice and picture recordings of the hearings. Eventually the legislator came to the compromising decision that written records of the hearings are of primary importance, which is obligatory in the entry section. In the substantive section, however, exceptionally, for the parties' request, if the technical conditions are at hand, the court can ordain the making of continuous and synchronical voice and picture recording. In this case the continuous recording is considered a record, and as a general rule, merely the abridgement of the procedure act is written simultaneously. ${ }^{21}$

\section{Conclusion}

In conclusion we can state that the new Civil Procedure Code, which comes into effect on 1 January, 2018, regards as its primary duty to close the processes quickly, efficiently, and successfully, as it adjusted the conceptual changes to this endeavour. We cannot expect, however, a radical change, since the new Civil Procedure Code primarily 
wished to raise the well-functioning judicial practice to a legal level in order to fulfil its aims. Whether these expectations were well-founded, can we give an established answer of course only after the law comes into effect, based on the future judicial practice.

\footnotetext{
* Habil. dr. associate professor, University of Debrecen Faculty of Law - Head of Civil Procedure Law Department; pribula74@freemail.hu.

${ }^{1}$ Varga, István - Éless, Tamás (editors): Szakértői javaslat az új polgári perrendtartás kodifikációjára. („Expert proposal about the codification of the new civil procedure code.”) HVG-Orac Kiadó, Budapest 2016.
}

${ }^{2}$ F. Rozsnyai, Krisztina: Közigazgatási bíráskodás Prokrusztész-ágyban. („Adminstrative jurisdiction in Procrustes' Bed.") ELTE Eötvös Kiadó, Budapest 2010.; Patyi, András: Közigazgatási bíráskodásunk modelljei - Tanulmány a magyar közigazgatási bíráskodásról. („Models of Administrative Jurisdiction Study on Hungarian Administrative Jurisdiction.”) Logod Bt., Budapest 2002.

${ }^{3}$ A polgári perrendtartásról szóló 2016. évi CXXX. törvény - „Hungarian Code of Civil Procedure, Act CXXX of 2016" - (hereinafter: Pp.) § 24 (3) -24. § (3)

${ }^{4}$ Pp. §264. (2).

${ }^{5}$ Constitutional Court Decision 1/2017 (I.17.)

${ }^{6}$ Udvary, Sándor: A jövő polgári perrendtartása madártávlatból. („The Civil Procedure Code of the Future from a Bird's-eye-view") Pro Futuro 2016/2., p.116.

7 Pp. §3.

${ }^{8}$ Pp. §4. (1)

${ }^{9} \mathrm{Pp} . \S 6$.

${ }^{10}$ Pp. $\$ 237$.

${ }^{11}$ Éless, Tamás - Döme, Attila: Alapvetések a polgári per szerkezetéhez. („Foundations of the Structure of Civil Procedure.”) In: Németh, János - Varga, István (editors): Egy új polgári perrendtartás alapjai. („Basis of a new civil procedure code.") HVG-Orac Kiadó, Budapest 2014., p. 74.

12 Interview with professor Zsuzsa Wopera, ministerial commissioner responsible for the management and co-ordination of the reform of the civil procedure code, creating the new regulatory system and the preparation of the laws involved. http://www.jogiforum.hu/hirek/36544 (2017.01.05.).

${ }_{13}^{13}$ Pp. $\$ 184$.

${ }^{14}$ Pp. §265. (2), (3)

${ }^{15}$ Novák, István: A bíró és a szakértő. Gondolatok egy gyakorlati témáról - több változatban. („The Judge and the Expert. Ideas on a practical topic - in several versions.") Magyar Jog 1991.6., p. 359.

${ }^{16}$ Pp. §370. (1), (3)

${ }^{17} \mathrm{Pp} . \S 381$.

${ }^{18}$ Harsági, Viktória: A kollektív igényérvényesítés hazai szabályozásának jövőjéről. („The Future of the Regulation of Collective Claim Assertion.") In.: Németh, János - Varga, István (eds.): Ibid. pp. 172.-173.

19 Pp. §571.-579.

20 Pp. $\$ 580 .-591$

${ }^{21}$ Pp. §159. (4). 